\title{
Realizing the Promise: India's Strategic Shift from Outsourcing to Innovation
}

\author{
Shewale Sunil ${ }^{*}$ and Parekh Sameer
}

Department of Medical Affairs/Clinical Research, Serum Institute of India Ltd., Pune. India

\begin{abstract}
Over the last decade the exclusive domain of pharmaceutical and biotechnology companies located in Western Europe and the United states have entered an era where they have become confronted by a variety of complex issues affecting their operational efficiency and profitability. Major issues being, the requirement to reduce the escalating costs and risks associated with drug development; and reduce clinical trial timelines by improving patient recruitment and improving the efficiency of clinical trial results analysis and reporting. In recent years there is drift; because the amount of clinical research and development activities conducted in emerging and non-traditional geographies has shown significant growth. The industry has recognized the opportunities and advantages that exist by conducting clinical trials in India; what is referred as the emerging market. As a result, many companies have flocked to India for better access to patients, lower costs and operational efficiencies. This article discusses the variety of factors that are behind the India's transformation from a simple outsourcing destination to a potential hub of true clinical research growth and innovation.
\end{abstract}

Keywords: Clinical trial, India, outsourcing, innovation.

\section{INTRODUCTION}

The foundation of knowledge-based industry in India was laid down by information technology and following the footsteps; clinical research is fast emerging and yet another powerful knowledge based industry of the new millennium [1]. For more than a decade, the emerging market of the India have held special promise for the global pharmaceutical industry. Driven by a combination of low per-capita consumption, rapidly expanding economies, technological innovation and talented workforce, the region has seen explosive growth in both economic and political power during the past few years and now India stand on the threshold of global superpower status. Multinational companies (MNCs) are facing number of problems such as declining research and development productivity, increasing development costs, decreasing pipelines and lower earnings, thus a veritable wave of western companies has set up shop in India and eager to capture a portion of the region's comparative advantages in talent costs, patient pools, medical skills and disease demographics.

As a result, the outsourcing to India is shifting from a tactical to strategic imperatives that build upon the region's experience and expertise. As pressure on pharma's development pipelines continues to grow, companies are setting their strategic sights on a future world where India is not just a market and support powerhouse for the industry, but the provider of key contributions to drug discovery and research innovation. In this regard, India as a whole may be posed to assume the veil of leadership and the strategic partner of choice for global pharmaceutical companies.

The Emergence of the Indian regulatory environment:

*Address correspondence to this author at the Department of Medical Affairs/Clinical Research, Serum Institute of India Ltd., 212/2, Off Soli Poonawalla Road, Pune-411028, Maharashtra, India; Tel: +91-9960980895; E-mail: ms.shewale85@gmail.com
Early Pharmaceutical pioneers in India faced a daunting task in operating in a regulatory and ethics environment that was unfriendly for quality clinical research [2]. Earlier sponsors often posed the question "Are Indian clinical trials accepted globally?" and it remained difficult to answer. But now it has become easier to encourage sponsors to consider India for their major clinical research plan; this is mainly because Indian government gradually progressed towards good clinical practice (GCP) standards and upgraded the guidelines related to clinical trials. Today clinical trial regulations and guidelines, clinical trial registry, ethics committee approval process has been implemented to make clinical trials in India, transparent, creditable and ethical. The chronology of the some of the changes made in regulations is given in Table 1.

Table 1. Chronology of Indian Regulation Related to Clinical Trials

- 1952: New Drug Definition

- 1970: Guidelines on introduction of new drug \& Clinical Trials

- 1988: Schedule Y, Rule 122A, 122B, 122C

- 2001: Amendment of Rule 122 (introduction of fee structure, PMS etc.)

- 2001: Indian GCP Guidelines

- 2005: Revised Schedule Y

- 2006: Indian Council of Medical Research-Ethical Guidelines for Biomedical Research

\section{5 - Road Sign for India}

Before 2005, number of trials conducted by pharmaceutical MNCs in India was insignificant. In January 2005, the Government of India upgraded Schedule Y of Drugs and Cosmetics Act of India, to complement it with International Conference on Harmonization (ICH) standards. These changes removed a number of regulatory barriers for performing clinical trials in India. The number of 
revolutionary changes which took place in 2005 within India are highlighted in Fig. (1).

- Considering the importance and growth of clinical research market, the Indian government has made the comprehensive definitions and described the conduct of trial.

- The specification for import of drugs for research and the requirement for GCP compliance trial within India, provided entry to global clinical trials.

- $\quad$ For more transparency and ethical conduct of a trial within country, Schedule $\mathrm{Y}$ has specified the Informed consent requirement and also launched the clinical trial registry.

- Due to legislation for intellectual property, many multi-national pharmaceutical companies and clinical research organizations (CROs) now look forward to India, as a big and valuable business partner.

$\bullet$

For compliance with international ethical and scientific quality standard and global acceptance of clinical trials data, the Indian government developed structured clinical study report format and has also defined the role and responsibilities of various stakeholders in clinical research.

\section{EXPANDING MARKET, INCREASING POWER}

India itself is one of the world's strongest emerging economies, growing at a 9 percent annual clip. It is also heavily populated (estimated 1.136 billion people), and has the potential to do clinical trials [3]. The Indian clinical trials market in 2009 was worth US\$ 320 million. By 2012 the clinical trial industry is expected to reach US\$ 630 million [4]. Various clinical trial phases and its percentage share in clinical trial scenario is demonstrated in Fig. (2) [2].

Similarly, the Fig. (3) illustrates the effect of such rapid growth on clinical trial market in India [5]. It projects that in 2011 over 300,000 patients will be enrolled in clinical trials in India and within five years 1,500 to 2,000 GCP studies will be conducted in India per year, requiring 10,000 to 15,000 GCP-trained investigators, supported by 50,000 clinical research professionals.

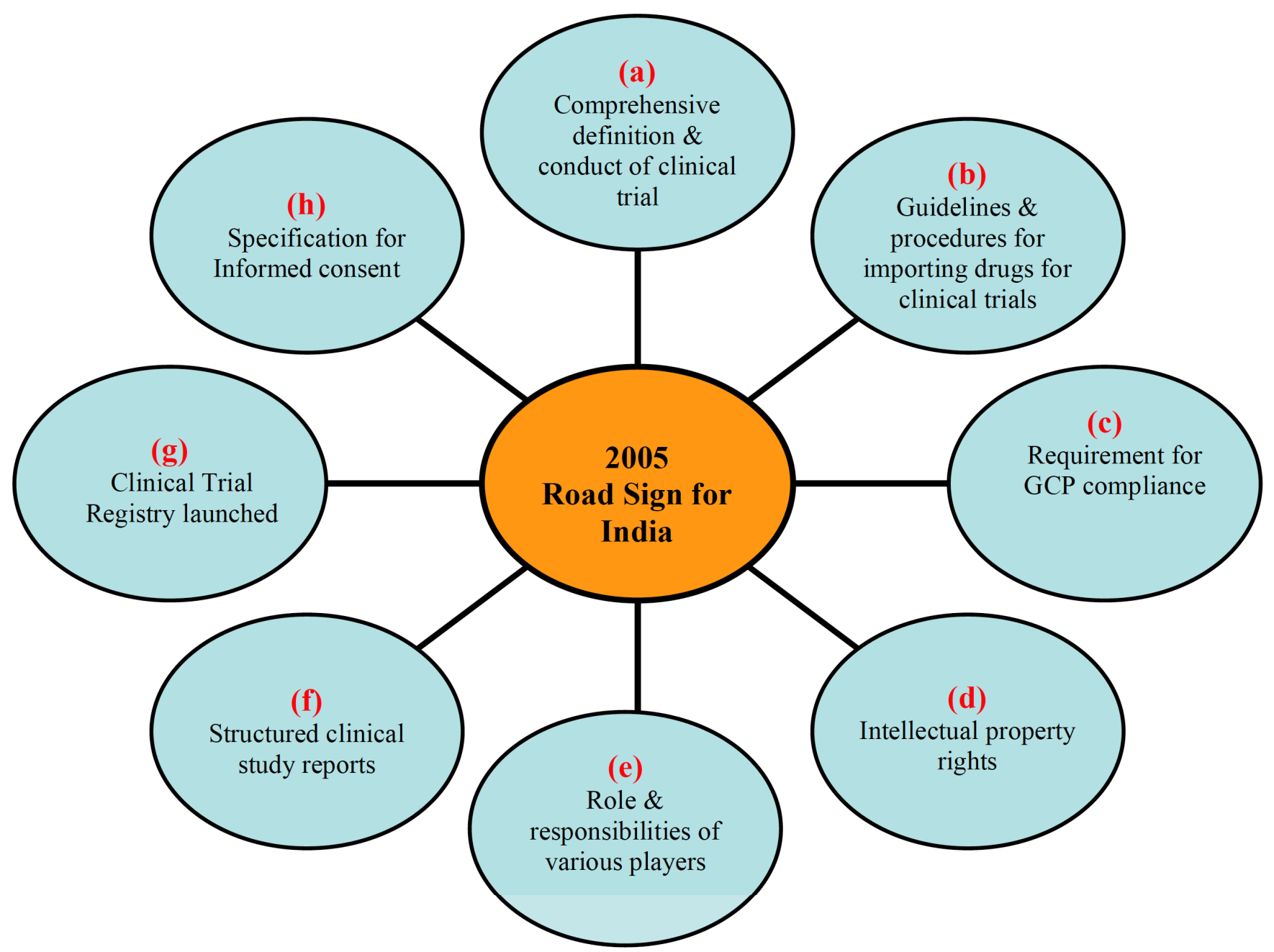

Fig. (1). Broad outline of changes takes place favouring clinical research in India in 2005. (a) Govt. of India meticulously defines the various terminology \& way to conduct the clinical trials. (b) Specification for drug import in India. (c) more focus on GCP compliance by direct or indirect participant in clinical trials. (d) protection of intellectual property of individual or of an organization. (e) defining the role \& responsibilities of sponsor, investigator, ethics committee \& others. (f) well structure \& formatting of clinical study report. (g) to register a clinical trial before testing on animal or human being. (h) protection of human being by well specified informed consent documents. 


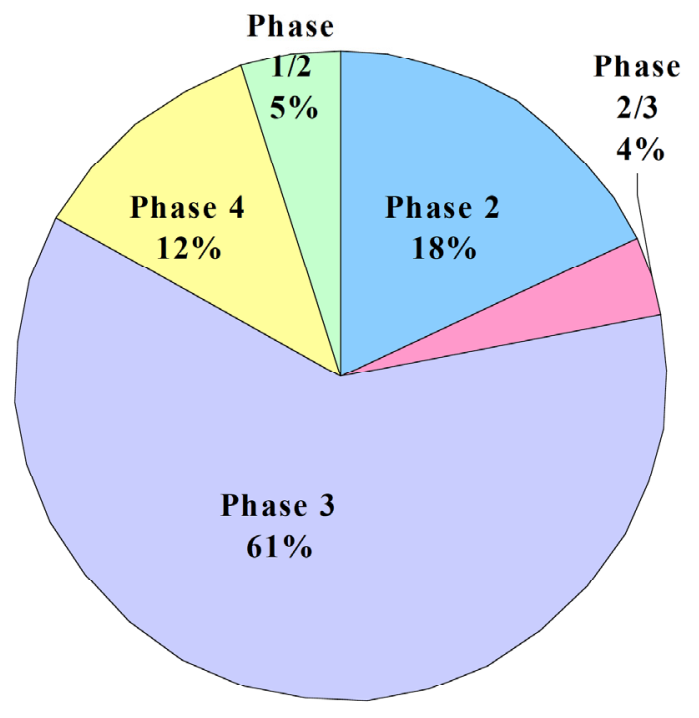

Fig. (2). Percentage share of clinical trial phases in India.

\section{CAPACITY OF INDIA TO MEET THE INCREASING DEMAND}

India has substantial setup to meet the rapidly growing demand for clinical trials. India has 300 universities, over 750 graduate and post-graduate programs, and about 50 million college graduates. India has 840,000 hospital beds in urban areas, over 600,000 English-speaking physicians and nearly 100,000 specialists, with many of them having been trained in the best global institutes. Similarly the number of investigators in India has also grown fast among Asian, Latin American and Eastern European countries [6]. The number of clinical investigators signing on to conduct Food and Drug Administration (FDA) regulated clinical trials rose by $29 \%$ to $39 \%$ in 2007 and represented $1.8 \%$ of total investigators around the world [7].

\section{CURRENT INDIAN REGULATORY ENVIRONMENT}

Clinical trials in India are now regulated by the Drugs Controller General of India (DCGI), who is responsible for assuring that all clinical trials comply with the requirements of the International Conference on Harmonization (ICH) of Technical Requirements for Registration of Pharmaceuticals for Human Use, as well as Good Clinical Practices.
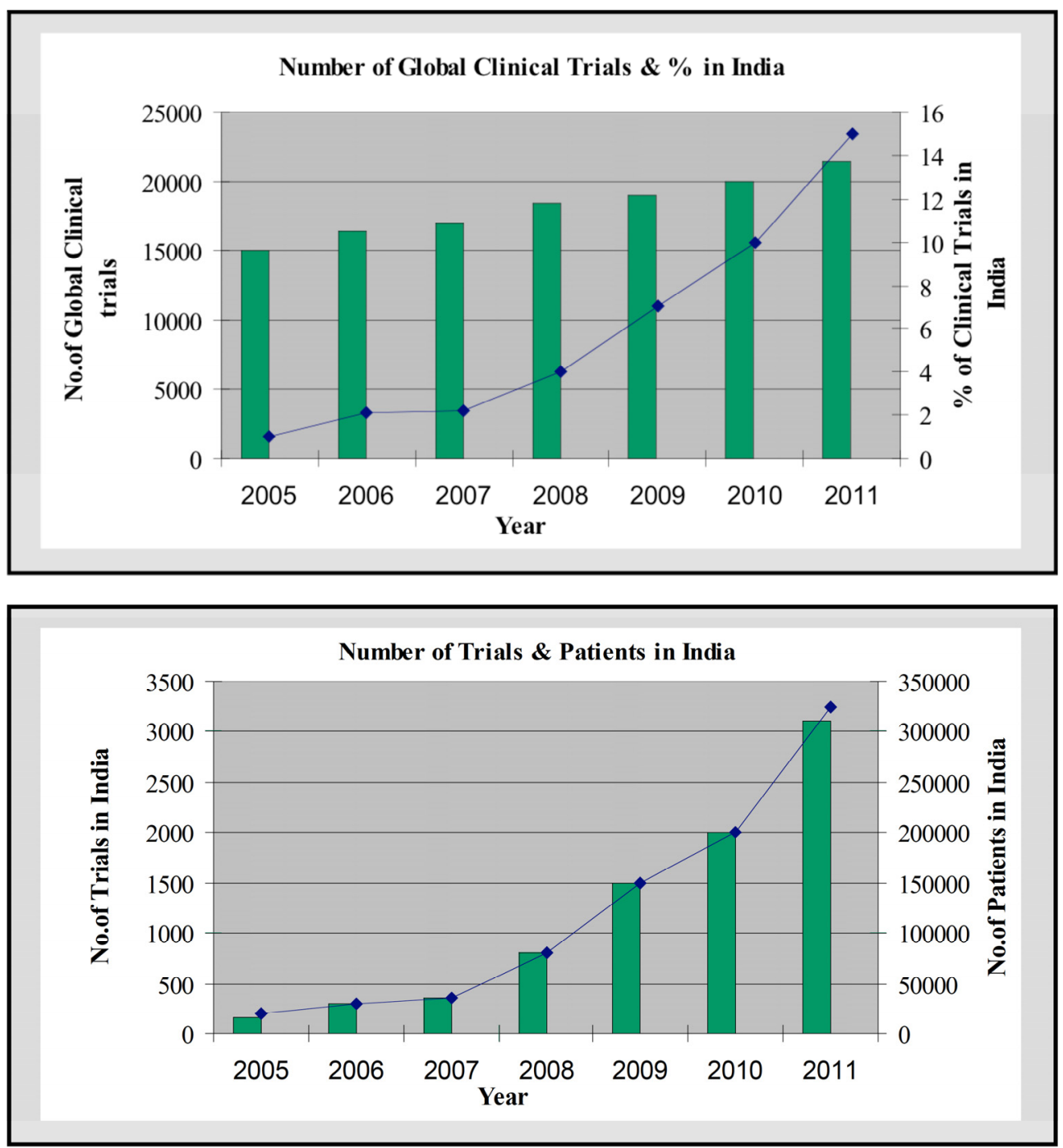

Fig. (3). Projection of Clinical Trials Market in India. 
The DCGI approval process categorizes clinical trials into two types. If the study protocol has already been approved by a cognizant regulatory authority in one or more developed countries (such as the United States, Canada, United Kingdom, Switzerland, Germany, Australia, Japan, and South Africa), the study is classified as a Type A trial and can be approved using a fast-track process within two to six weeks after the required documentation has been submitted. All other studies are classified as Type B and the approval process generally takes eight to twelve weeks.

The Ethics Committee (EC) approval process can be conducted in parallel with the DCGI review and, if import licenses are needed, the applications for those can also proceed in parallel. These provisions facilitate the process of getting study protocols in place and quickly initiating the trials.

Recently, the Indian government has started offering incentives to domestic and multinational drug makers to encourage new drug discovery [8]. Similarly government also provide tax exemption on all profits for companies that conduct in-house research and development, such activities will definitely help to turn the country into one of the top five pharma innovation hubs by 2020. Also India is planning to create an independent drug regulatory authority that will emulate the U.S. Food and Drug Administration within the next two years [9]. This central group will lead to more rigorous and consistent drug regulations and higher overall standards.

\section{COST EFFICACY}

Globally, there is a pressure on pharma companies to reduce costs on drugs by government agencies. Thus, very few new drugs are coming out and also the patents of many blockbuster drugs are nearing expiry. This is pressuring the pharma companies to push as many compounds as possible to the market despite the stringent FDA and regulatory authority demands [10]. Thus in such situation wherein cost factor is so important, the pharmaceutical companies are looking for new destination which will provide an advantage.

In terms of the cost efficiency, India works out to be a cheaper option as the cost to conduct a trial here is lower by 50 to $75 \%$ than that in either United States or European Union. Research and development cost in India is much less than those in the developed world and it is possible to conduct both New Drug Discovery Research and Novel Drug Delivery System programs at competitive rates [11]. The assessment of macro and micro view of costing in India and western world is briefed in Tables $\mathbf{2}$ and $\mathbf{3}$ respectively [5].

\section{INFRASTRUCTURE}

Participation in global clinical trials requires an improvement in existing infrastructure and facilities at a majority of hospitals in terms of functioning of institutional ethics committee, calibration and quality control of diagnostic equipments, maintenance of patient medical records, handling of investigational product, and other critical areas.
Table 2. Cost Macro View

\begin{tabular}{|c|c|c|}
\hline $\begin{array}{c}\text { Pre Clinical Trial } \\
\text { (Estimates) }\end{array}$ & Clinical Trials (Estimates) & $\begin{array}{c}\text { Time Equals } \\
\text { Money }\end{array}$ \\
\hline \hline $\begin{array}{c}\text { Toxicology- } 30 \% \\
\text { cost of the West }\end{array}$ & $\begin{array}{c}\text { Phase I- } 25 \% \\
\text { cost of the West }\end{array}$ & $\begin{array}{c}\text { Patient } \\
\text { recruitment }\end{array}$ \\
\hline $\begin{array}{c}\text { Animal Testing-30\% } \\
\text { cost of the West }\end{array}$ & $\begin{array}{c}\text { Phase II/III- } 30 \% \\
\text { cost of the West }\end{array}$ & $\begin{array}{c}\text { Pre-clinical } \\
\text { regulations }\end{array}$ \\
\hline
\end{tabular}

Table 3. Cost Micro View

\begin{tabular}{|c|c|c|}
\hline Item & US cost & Indian cost \\
\hline \hline 1 Day stay in Hospital & $\$ 750$ to $\$ 1000$ & $\$ 40$ to $\$ 100$ \\
\hline 1 Day stay in ICU & $\$ 1500$ to $\$ 2000$ & $\$ 80$ to $\$ 150$ \\
\hline CT Scan & $\$ 300$ to $\$ 550$ & $\$ 100$ to $\$ 150$ \\
\hline MRI & $\$ 1500$ to $\$ 3500$ & $\$ 150$ to $\$ 300$ \\
\hline ECG & $\$ 30$ & $\$ 4$ to $\$ 6$ \\
\hline $\begin{array}{c}\text { Annual salary of } \\
\text { specialized doctor }\end{array}$ & $\$ 225000+$ & $\begin{array}{c}\$ 40000+\text { for } \\
\text { key opinion leaders }\end{array}$ \\
\hline
\end{tabular}

India has a talented pool of clinical research professionals and infrastructure, which includes all super specialties of medicine, advanced diagnostic tools. Professionals from disciplines like pharmacy, nursing, and lab technology are available in abundance, who could be involved in activities like monitoring of clinical trials, project management, study coordinators and data management. Similarly, the pharmaceutical companies and CROs are bringing change in their business culture within India from developing to developed phase so that to match with the existing sharp edge competition. Some of the basic administrative changes which have been adapted by various clinical research organizations are given in Fig. (4).

\section{PATIENT POPULATION AND WIDE SPECTRUM OF DISEASE}

India has the largest pool of around 20 million patients suffering from the Diabetes. Other diseases like multi-drug resistant pneumonia, hepatitis B and some cancers are far more prevalent in India than in west. Moreover, country's large poor-patient population is "treatment naive", which means they have never received drugs for treatment. These facts indicate that, getting a required patient pool for trial is not a difficult task and thus, it simplifies patient enrollment and trial management in India.

Apart from the sheer numbers of patients, there are other compelling reasons why multinational drug companies are looking towards India for new drugs. For example, India's huge patient population offers vast genetic diversity, making the country "an ideal site for clinical trials". Thus, testing a drug on different ethnic groups can help to determine how drugs work differently in various racial groups and among other things and/or whether different dosages are required in different ethnic populations [12]. Also the fact remains, since this huge population itself is the market; the pharma 


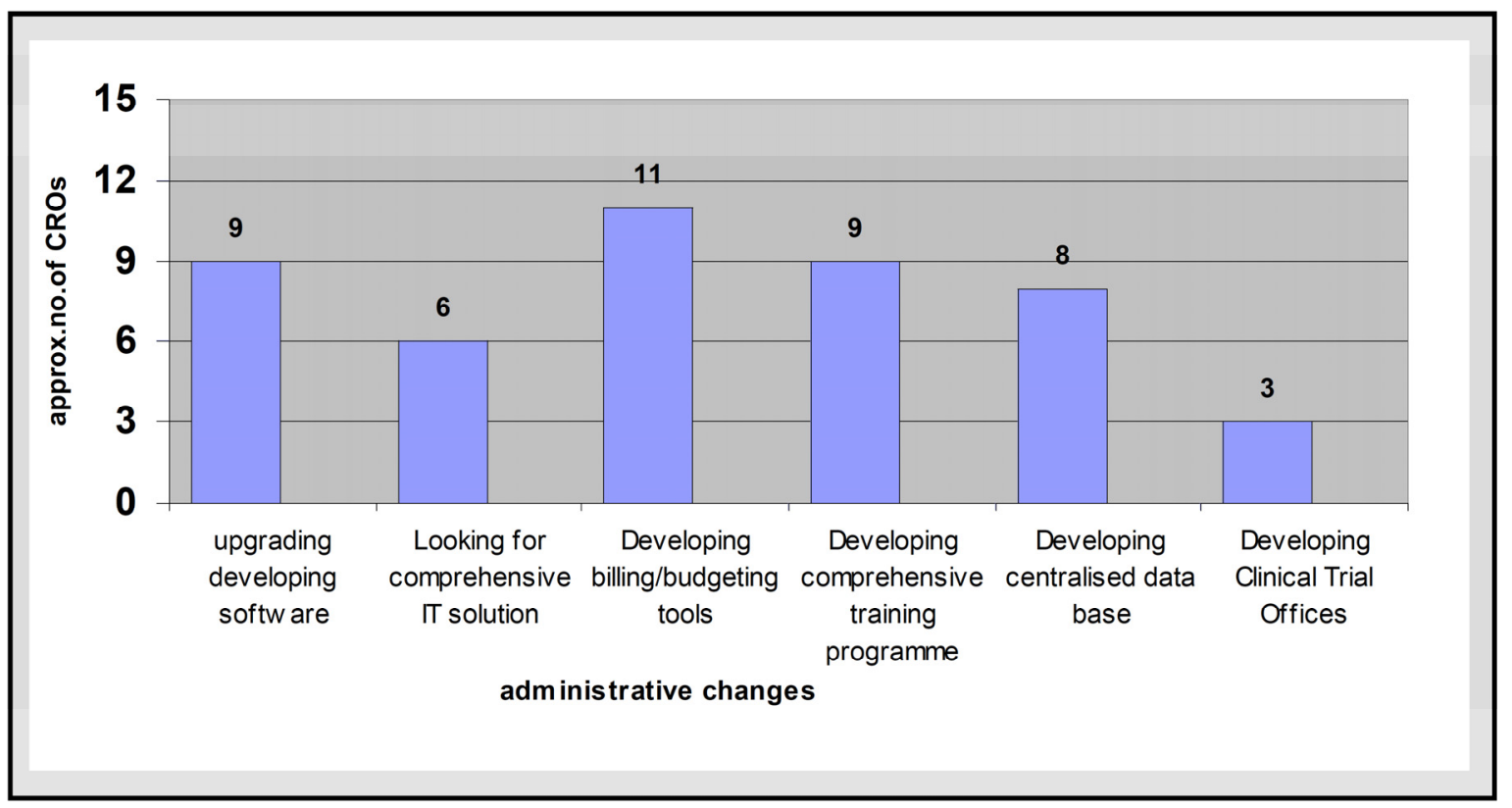

Fig. (4). New business culture of CRO in India.

companies can not ignore the business here and as per regulatory, if they wish to market their product in India, clinical research among local population is desired. Facts related to Indian population and a major threatening diseases has been mentioned in Table 4 [6]. Similarly Table 5 shows the number of trials ongoing in the various therapeutic areas.

Table 4. Indian Patient Population: Fact Sheet

\begin{tabular}{|c|c|}
\hline $\begin{array}{l}\text { - } 2 \text { millions adverse cardiac event } \\
\text { - } \quad 34 \text { millions Diabetics } \\
\text { - } \quad 8-10 \text { millions HIV +ve } \\
\text { - } \quad 3 \text { millions cancer patients } \\
\text { - } \quad 8 \text { millions Epileptic }\end{array}$ & $\begin{array}{l}\text { - } 1.5 \text { millions Alzheimer patients } \\
\text { - } 1 \text { millions PD patients } \\
\text { - } 40 \text { millions Asthmatic } \\
\text { - } 15 \% \text { Hypertensive } \\
\text { - } 1 \% \text { Schizophrenia patients }\end{array}$ \\
\hline
\end{tabular}

\section{SUBJECT RECRUITMENT}

Subject recruitment is the most common rate-limiting step in the drug development process. Sponsors normally cannot reduce study timelines without sacrificing quality and incurring increased cost. The relative cost savings result not only from shorter timelines but also from the low cost of performing studies in India. Due to the high population density of the urban areas and relatively small number of hospitals, recruiting a large number of subjects within a short time frame is not difficult. Also, the accessibility of these hospitals allows cost effective monitoring of studies.

Subject compliance is an important side of clinical trials. Generally subjects recruited in the studies performed in India are not only treatment naïve but also recognize that study participation can offer access to quality health care and medicines that may not be otherwise affordable to them. As a result, subjects are very compliant and are keen to attend all their study visits. For instance, an independent study by a global CRO concluded that India has one of the best subject return rates in the world [13].
Table 5. Ongoing Clinical Trials on Various Therapeutic Areas in India

\begin{tabular}{|c|c|c|}
\hline Sr.No. & Categories & Number of Trials \\
\hline \hline 1 & Nervous & 212 \\
\hline 2 & Respiratory & 159 \\
\hline 3 & Immune & 125 \\
\hline 4 & Oncology & 80 \\
\hline 5 & Diabetic & 58 \\
\hline 6 & Urinary tract disease & 27 \\
\hline 7 & Blood disease & 208 \\
\hline 8 & Digestive system & 141 \\
\hline 9 & Heart disease & 121 \\
\hline 10 & ENT & 64 \\
\hline 11 & Behaviors and mental & 40 \\
\hline 12 & Viral disease & 20 \\
\hline & Total & $\mathbf{1 2 5 5}$ \\
\hline
\end{tabular}

Note: Above details are till date January 2010.

\section{QUALITY OF DATA}

Numerous audits conducted in India by international regulatory authority, local regulatory authority, various multi national companies and CROs indicate that, captured clinical trial data is of good quality. Since quality is the hallmark of global acceptance, most sponsors and CROs working in India, invest heavily in investigator training, monitoring and quality control. Due to these reasons the data from clinical studies in India have been successfully filed with international regulatory agencies. The overall impression is that the data quality is excellent [14]. 


\section{CLINICAL DATA MANAGEMENT}

Access to a large resource pool with IT and business process skills in a low-cost labor environment provide the basis for cost-effective data management services by large numbers of IT-literate biomedical graduates. India ideally positioned for the widespread adoption of EDC technologies to prevalent high-speed Internet connectivity and absence of the biases stemming from the use of legacy systems [15].

\section{ASSOCIATION}

India established its strength in developing, manufacturing and marketing generic products for global market. This success is attributed primarily to its strength in the process chemistry, formulation development and manufacturing areas. A number of contract research organizations, pharma companies from developed countries forging $R \& D$ alliances with Indian companies because they offer quality and cost-effective services in medicinal chemistry, formulation development, and toxicology areas. These alliances are giving preclinical candidates or clinical candidates with proof of concept in humans.

\section{RECOGNIZED PHARMA COMPANIES}

Indian companies have already proven its capabilities in discovering and developing drug candidate molecules and they are highly capable in research and development particularly in drug discovery. There are opportunities to apply modern science to elucidate molecular mechanism of action and to identify active ingredients of various traditional medicines. Similarly, the process of reverse pharmacology can be applied to discover new drug candidate molecules from these traditional medicines.

\section{ALIGNMENT WITH WORLD TRADE ORGANIZATION}

In 1995 the Indian government as part of the World Trade Organization (WTO) agreed to adhere to the product patent regime by 2005 [13]. India has implemented product patent laws since 2005 and they got authenticity of internationally recognized product patent, which will lead to widening of the market for all sectors including pharma. The Product patent protection has encouraged multinational companies to import technology into India to develop new products. These developments have helped to open up increased opportunities for the clinical trials of bio-tech and medicinal products [16].

\section{ETHICAL CLINICAL TRIALS}

Scientific misconduct is a global phenomenon linked to human behavior rather than to an individual country. Companies acting ethically set globally consistent standards and conduct trials only in the countries where GCP compliance is assured. Thus FDA has increased its surveillance over clinical research programs [17].

The Indian regulatory authority is also in the process of setting up surveillance teams for ensuring ethical conduct of clinical trials. Indian investigators have demonstrated their compliance by virtue of participation in more than 60 global trials so far. Moreover, a majority of those trials were FDA or European registration trials, requiring strict compliance with GCP and regulatory guidelines. Table 6 describes recent
Initiatives by Central Drug Standard Control Organization (CDSCO) for Promoting Ethical Clinical Research.

Table 6. Recent Initiatives by CDSCO for Promoting Ethical Clinical Research

- Review of proposal- Time lines

- Phase 0, Phase-1 and Micro dosing trial- initiatives

- Guidance on Clinical Trial Inspection-November 2010

- Rule 122 DAB : Registration of CROs for conducting clinical trialsJan 2011

- Draft guidelines for reporting Serious Adverse Event- May 2011

\section{CONCLUSION}

Clinical trials can provide answer regarding, the potential use of any therapeutic agent that can benefits millions of patients worldwide. But conducting clinical trial is costly affair with uncertainty. Thus concept of outsourcing for the drug development and global studies on new drugs has become widely accepted in the pharmaceutical industry. Being the second most populated country in the world, multinational pharma companies has recognize the benefits of outsourcing trial activities to India. Similarly, India on its front gaining increased prominence by its ability to keep up with the emerging science and to adapt its regulatory oversight accordingly. Because of this India has now become a new center of gravity to global drug development programs and many companies successfully navigate risk and seize the opportunities in this new health landscape and trying to further advance their portfolios. Regardless of all the pitfalls, the country is ambitious and setting up the new health equation. Thus, by realizing the promises offer by India the patients, payers, policymakers, providers, pharma companies strategically shifting India from simple outsourcing destination to new center of innovation and making it a potential hub of clinical research.

\section{ACKNOWLEDGEMENT}

The author wish to thank Ms. Maryam Shaikh for her valuable cooperation. We thank Mr. Ilyas \& Mr. M. Hashim Shah for proofreading the manuscript.

\section{CONFLICT OF INTEREST}

None Declared.

\section{REFERENCES}

[1] Dua G, Gupta S. Clinical research-destination India. Pharmabiz Chronicle, July 17, 2003. Available from: http://www.pharmabiz. com/article/detnews.asp?articleid $=17307 \&$ sectionid $=50$

[2] India Today. India's clinical trials market accelerates. BioPharm International. May 2008. Available from: http://www.bioplanas sociates.com/publications/articles/IndiaTodayCTs-KermaniLanger414-08.pdf

[3] India becoming favored destination for clinical trials. Bio.ITWorld January 22, 2008. Available from: http://www.bio-itworld.com/ newsitems/2008/jan/22-clinical-trials-india/

[4] Clinical trials in India-2010. Research \& Markets-World's Largest Market Research Resource. Feb 2010. Available from: http://www. researchandmarkets.com/reportinfo.asp?-report_id=1212074

[5] Adeshara S. Exports \& clinical trials for me-dical devices. PPT. Available from: http://pharmexcil.com/data/uploads/Export $\% 20 \&$ \%20Clinical\%20Trials.ppt\#256,1, Exports \& clinical trials for medical devices

[6] India preferred destination for clinical trials shows study. IANSThaindian News. August 09, 2009. Available from: http://www.tha 
indian.com/newsportal/business-/india-preferred-destination-forclinical-trials-shows-study 100229859.html

[7] Cooper AM. Pursuing quality clinical research in India. dia global forum (35). Available from: http://www.parexel.com/index.php/do wnload file/view/67/

[8] Centre may inject $\$ 2 \mathrm{bn} / \mathrm{yr}$ into drug research. The Economic Times. March 2, 2009. Available from: http://economictimes.india times.com/news/economy/finance/Centre-may-inject-2-bn/yr-into drug-research/articleshow/4210074.cms

[9] Bailey W, Cruickshank C, Sharma N. Make your move: taking clinical trials to the best location. Available from: http://www.atke arney.com/index.php/publications/make-your-move.html

[10] Sangeetha G. India turns hub of clinical research outsourcing. Financial chronicle. May 26, 2009. Available from: http://www.my digitalfc.com/knowledge/india-turns-hub-clinical-researchoutsourcing-105

[11] Gupta SK. Maximizing benefits of clinical research. In Pharmabiz chronicle.Oct.27, 2005. Available from:http://www.pharmabiz. com/article/detnews.asp? articleid $=30398 \&$ sectionid $=50$
[12] Questions \& answer-why to choose India for conducting clinical trials; Catalyst Clinical Services Pvt. Ltd. - A Clinical Development Organization. Available from : http://www.catalystclinica lservices.com/documents/WHY\%20TO\%20CHOOSE\%20INDIA $\% 20 \% 20$ CLINICAL\%20TRIALS.doc

[13] Khan Y. Clinical trials in India. Pharm-Olam International Ltd Available from: http://www.pharm-olam.com/pdfs/Clinical\%20Tr ials\%20in\%20India.pdf

[14] Bhatt A. Clinical trials in India: Pangs of globalization. India J Pharmacol 2004; 38(4): 207-8.

[15] Nermeen Varawalla. Conducting clinical trials in Asia. Applied Clinical Trials; Sep.2010; Available from: http://appliedclinical trialsonline.findpharma.com/appliedclinicaltrials/article/articleDeta il.jsp id $=687150 \&$ sk $=\&$ date $=\&$ page $I D=5$

[16] Chabukswar AR, Parakh SR, Jagadale S. Clinical trials-present \& future in India. Pharmainfo.net. Available from: http://www.pha rmainfo.net/reviews/clinical-trials-present-and-future-india

[17] Julka PK. Clinical trials in India-dilemmas for developing countries. Monitor 2007; 70-1.

(C) Sunil and Sameer; Licensee Bentham Open.

This is an open access article licensed under the terms of the Creative Commons Attribution Non-Commercial License (http://creativecommons.org/licenses/by$\mathrm{nc} / 3.0 /$ ) which permits unrestricted, non-commercial use, distribution and reproduction in any medium, provided the work is properly cited. 